San Jose State University

SJSU ScholarWorks

Master's Theses

Master's Theses and Graduate Research

Summer 2018

\title{
Job Level and Job Family as Predictors of Preferences for the Physical Environment
}

\author{
Rachel Smith \\ San Jose State University
}

Follow this and additional works at: https://scholarworks.sjsu.edu/etd_theses

\section{Recommended Citation}

Smith, Rachel, "Job Level and Job Family as Predictors of Preferences for the Physical Environment" (2018). Master's Theses. 4955.

DOI: https://doi.org/10.31979/etd.pc5y-3475

https://scholarworks.sjsu.edu/etd_theses/4955

This Thesis is brought to you for free and open access by the Master's Theses and Graduate Research at SJSU ScholarWorks. It has been accepted for inclusion in Master's Theses by an authorized administrator of SJSU ScholarWorks. For more information, please contact scholarworks@sjsu.edu. 


\title{
JOB LEVEL AND JOB FAMILY AS PREDICTORS OF PREFERENCES FOR THE PHYSICAL ENVIRONMENT
}

\author{
A Thesis \\ Presented to \\ The Faculty of the Department of Psychology \\ San José State University
}

\author{
In Partial Fulfillment \\ of the Requirements for the Degree \\ Master of Science
}

by

Rachel Colleen Smith

August 2018 
(C) 2018

Rachel Colleen Smith

ALL RIGHTS RESERVED 
The Designated Thesis Committee Approves the Thesis Titled

JOB LEVEL AND JOB FAMILY AS PREDICTORS OF PREFERENCES FOR THE PHYSICAL ENVIRONMENT

\author{
by \\ Rachel Colleen Smith \\ APPROVED FOR THE DEPARTMENT OF PSYCHOLOGY \\ SAN JOSÉ STATE UNIVERSITY
}

August 2018

$\begin{array}{ll}\text { Howard Tokunaga, Ph.D. } & \text { Department of Psychology } \\ \text { Megumi Hosoda, Ph.D. } & \text { Department of Psychology } \\ \text { David Staffanson, MBA } & \text { VP of Human Resources, Varian }\end{array}$ 


\title{
ABSTRACT \\ JOB LEVEL AND JOB FAMILY AS PREDICTORS OF PREFERENCES FOR THE PHYSICAL ENVIRONMENT
}

\author{
by Rachel Colleen Smith
}

Previous research shows that the physical work environment is related to various work-related employee outcomes. However, researchers have not focused on employee preferences for the physical work environment, nor predictors of such preferences. The current study proposed that job level and job family might predict employee preferences for the layout and design of work environments. The study also examined gender and age as moderators of the relationship between job level and employee preferences, and the relationship between job family and employee preferences. The results of online surveys from 157 employees of a medical technology company showed that job level predicted employee preferences such that non-managers had stronger preferences than managers for the sights and sounds in a workspace. Results also demonstrated that female managers preferred a visually appealing workspace more strongly than female non-managers. Female engineers were found to prefer a more closed, private, and non-distracting work environment than female non-engineers, whereas male non-engineers were found to prefer a workspace with a low level of noise and distraction more strongly than male engineers. Age was not found to moderate any of the relationships. Theoretical implications of this study include that employee preferences for the physical environment are somewhat predictable and should be further investigated. Results of the present study provide guidance for practitioners who are interested in optimizing the design of physical work environments. 


\section{ACKNOWLEDGMENTS}

I would like to express my sincerest thanks to Dr. Howard Tokunaga for supporting me via countless emails, phone calls, and meetings throughout the past year. It couldn't have been easy guiding an indecisive student like me, who started with approximately 53 topic ideas and struggled to narrow it down to one. I would also like to thank Dr. Megumi Hosoda, for her keen eye and genuine interest in my topic. Your dedication to this project, especially in the last few weeks, was greatly appreciated. Thank you both for leading me through this process.

I am equally grateful for my colleagues at Varian Medical Systems, particularly David, Lisa, and Tom. Thank you for believing in me and seeing the value of this project, both in theory and practice. Your support helped make the completion of this thesis (and my degree) possible!

Thank you to my parents and sisters for your unconditional love, and for sharing your food when I was too busy to cook. You've all helped me more than you know. Finally, Artur, thank you for encouraging me to undertake graduate school, for your never-ending patience, and for all the loving pep talks along the way. I'm so lucky to have you all. 


\section{TABLE OF CONTENTS}

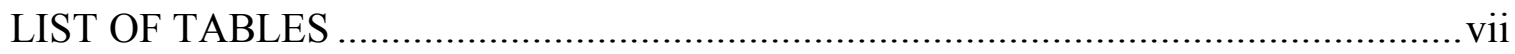

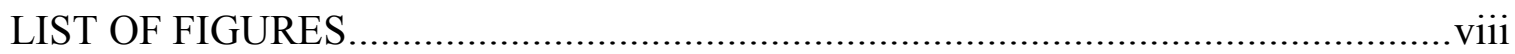

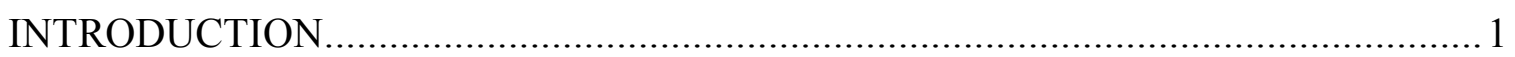

Definitions and Dimensions of Physical Environment............................................... 1

The Effects of Physical Environment: Work-Related Outcomes.................................. 4

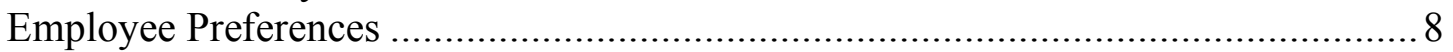

Predictors of Preferences for Physical Environment................................................ 9

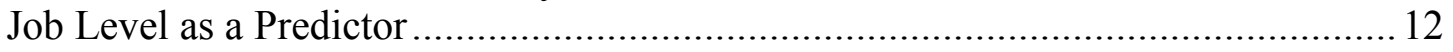

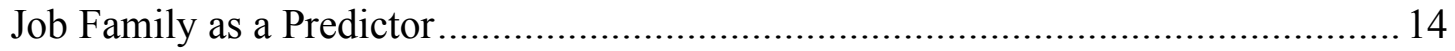

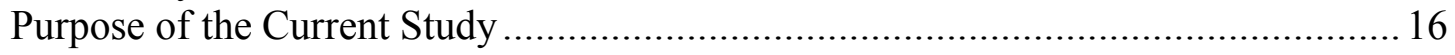

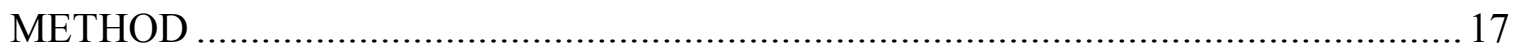

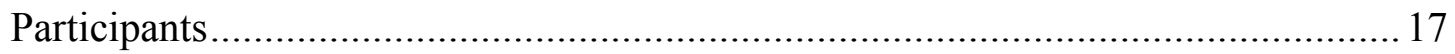

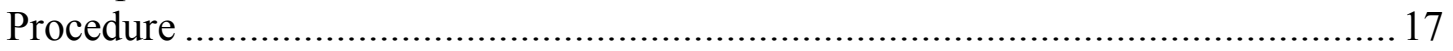

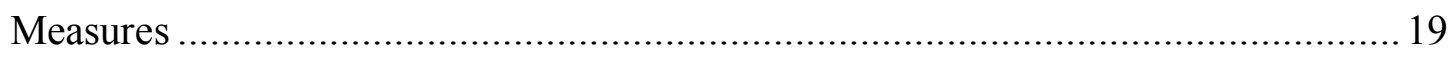

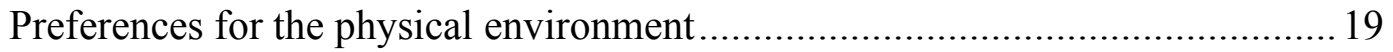

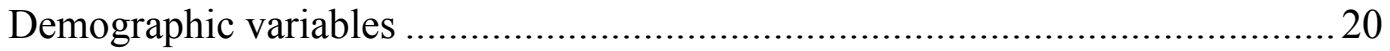

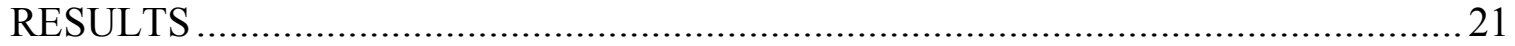

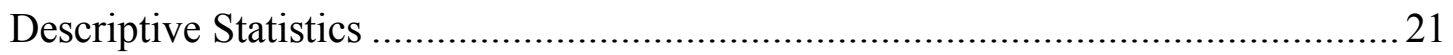

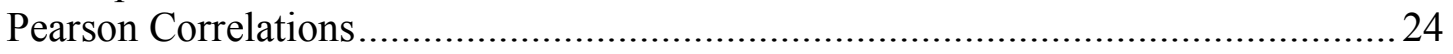

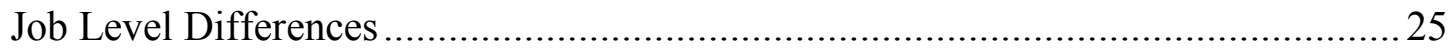

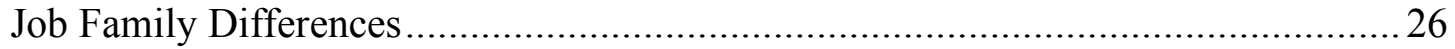

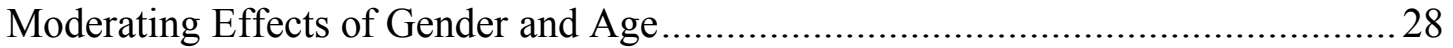

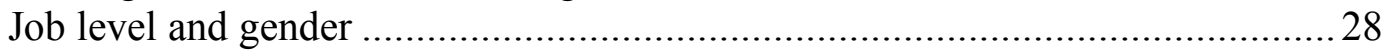

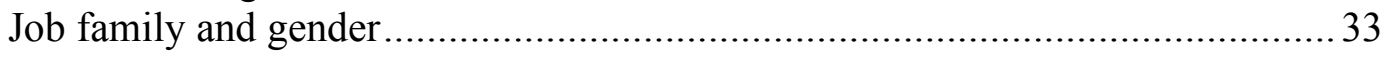

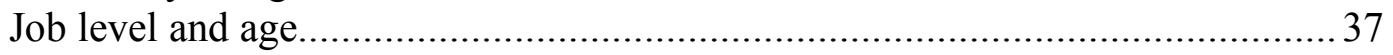

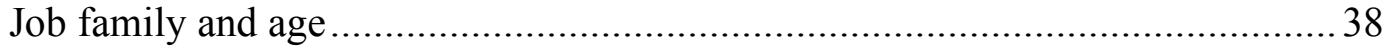

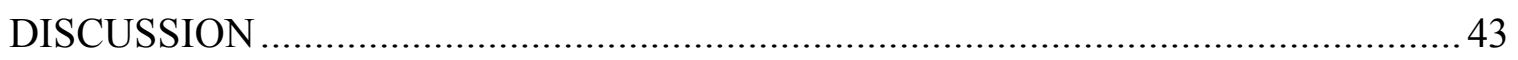

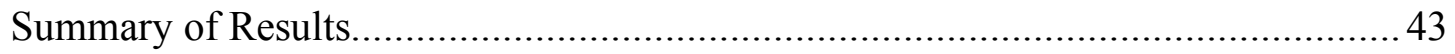

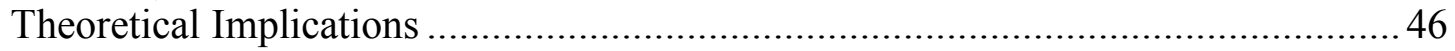

Practical Implications .................................................................................. 48

Strengths, Limitations, and Future Research ………….......................................... 49

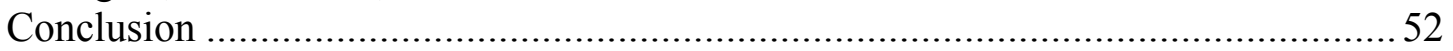

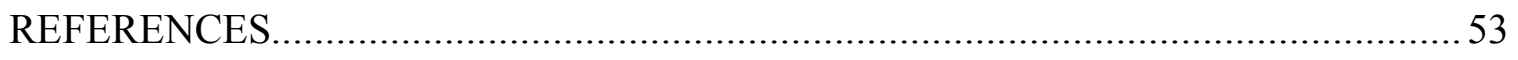

APPENDIX

Survey Items 


\section{LIST OF TABLES}

Table 1. Demographic Characteristics of Participants

Table 2. Descriptive Statistics, Preferences for the Physical Environment

Scale Items

Table 3. Pearson Correlations and Cronbach's Alphas

Table 4. Results of t-Tests and Descriptive Statistics for Physical Environment Preferences by Job Level

Table 5. Means, Standard Deviations, and One-Way Analyses of Variance

(ANOVAs) for Effects of Job Family on Preferences for the Physical

Environment

Table 6. Two-Way ANOVA for Preferences for the Physical Environment as a Function of Job Level by Gender 30

Table 7. Means and Standard Deviations for Preferences for the Physical Environment as a Function of Job Level and Gender

Table 8. Two-Way ANOVA for Preferences for the Physical Environment as a Function of Job Family by Gender

Table 9. Means and Standard Deviations for Preferences for the Physical Environment as a Function of Job Family and Gender

Table 10. Two-Way ANOVA for Preferences for the Physical Environment as a Function of Job Level by Age

Table 11. Means and Standard Deviations for Preferences for the Physical Environment as a Function of Job Level and Age

Table 12. Two-Way ANOVA for Preferences for the Physical Environment as a Function of Job Family by Age

Table 13. Means and Standard Deviations for Preferences for the Physical Environment as a Function of Job Family and Age 


\section{LIST OF FIGURES}

Figure 1. Mean scores for male and female managers and non-managers on

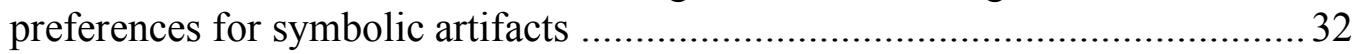

Figure 2. Mean scores for male and female engineers and non-engineers on preferences for physical structure

Figure 3. Mean scores for male and female engineers and non-engineers on preferences for physical stimuli 


\section{Introduction}

It is widely accepted that individuals' thoughts and behaviors are directly affected by the space around them (Doorley \& Witthoft, 2012). Psychologists, designers, and human factors experts have pondered this idea for decades, often through the lens of the workplace. Does the presence of a sofa in a common area at work lead to increased collaboration? Can leaders of organizations improve productivity by changing the temperature in the building? Does rearranging the office layout encourage a friendlier culture? Does space affect all employees in the same ways? Researchers and practitioners alike are interested in the answers to these types of questions. To help maximize positive outcomes of the physical environment, it would be useful to first consider employee preferences for the physical environment. As preferences surely vary on an individual basis, perhaps it would be helpful to understand common preferences within groups of employees. Because all employees fall into a job level and a job family, these could be useful groupings for the study of employee preferences for the physical environment. The purpose of this study was to determine how job level and job family predict employee preferences for the physical environment.

\section{Definitions and Dimensions of Physical Environment}

Throughout the existing literature, researchers have employed various terms and definitions to address the space in which employees perform work. Some definitions are designed to build on existing ones, and others are conceptualized independently to suit varying research needs. One of the early and prominent conceptualizations of the topic was Davis's (1984) “physical environment.” In the context of Davis's research, the 
physical environment is an office setting that can influence employee behavior. It consists of three primary dimensions: physical structure, physical stimuli, and symbolic artifacts. Taken together, these dimensions describe the physical environment in both a material sense and an abstract sense.

Within his discussion of the physical environment, Davis provides a specific description of each dimension. Physical structure refers to the "architectural design and physical placement of furnishings in a building that influence or regulate social interaction" (Davis, 1984, p. 272). For example, walls and hallways are parts of the physical structure. These may be permanent or subject to change, as when a partition between cubicles is removed. Second, physical stimuli include aspects of the work setting that attract employee attention and influence behavior, such as ringing telephones, incoming emails or chats, and the smell of coffee. Symbolic artifacts compose the third and final dimension: "aspects of the physical setting that individually or collectively guide the interpretation of the social setting" (p. 276). These artifacts convey information about the company or the people working at the company. Design, style, and color are common illustrations of symbolic artifacts. For example, a couch made of sturdy, dark leather may be a symbolic artifact denoting power and wealth.

Becker and Steele (1995) coined the term "high-performance workplace" in their book Workplace by Design. They define a high-performance workplace as a single, integrated system in which "physical setting, technology, work processes, management style, and organization philosophy and values are in harmony" (p. 4). This definition refers to both physical and abstract aspects of a work setting, though it is more complex 
than Davis's conceptualization. Becker and Steele's (1995) portrayal of the highperformance workplace involves dimensions that are difficult to measure and are not widely recognized as elements of a physical environment in other literature. For example, Becker and Steele's dimension of management style involves the ways in which a leader makes decisions and interacts with direct reports. By this definition, management style is not associated with physical space, and is difficult to measure and manipulate. For these reasons, Becker and Steele's (1995) high-performance workplace is not a suitable term for the purposes of the current study.

More recent researchers have continued to reinvent the concept and dimensions of physical environment. Some authors consider "physical environment," "work environment," and "office space" as synonymous terms (Vilnai-Yavetz, Rafaeli, \& Schneider Yaacov, 2005). Regardless of the term used, the construct is composed of three dimensions: instrumentality, aesthetics, and symbolism. In this model, the instrumentality of an object affords a "physical artifact to support or hamper a desired activity" (p. 535). For example, the instrumentality of a desk ranges from a surface on which to write, a surface on which to lean or sit, or a surface on which to rest a laptop. The aesthetics dimension refers to the appearance of an object or space, for example, the beauty or ugliness of furniture in an office. Last, the dimension of symbolism refers to associations elicited by the space, such as a crystal plaque signifying prestige or success. Like Davis (1984), the authors divide the physical environment into three elements; however, two of the three dimensions (aesthetics and symbolism) account for abstract aspects of the work environment. Upon comparison of these dimensions to those created by Davis (1984), 
only one of Davis's dimensions is abstract (symbolic artifacts). For this reason, Davis's dimensions are better able to capture tangible aspects of the physical environment. Consequently, as the current study's purpose was to study observable dimensions of the physical environment, Vilnai-Yavetz et al. (2005) did not sufficiently capture the tangible aspects of the environment, therefore rendering the definition unfit for the present study.

Although each of the above definitions adds value to the existing body of literature, the work by Davis (1984) is most prevalent in research today. Davis acknowledges that different conceptualizations may be appropriate in different situations, and asserts that his conceptualization is most appropriate for researchers who seek to "discover how [individuals] can manipulate or rearrange the physical environment to support more efficient behavior at work" (p. 281). Physical structure, physical stimuli, and symbolic artifacts are directly measurable and observable qualities of the physical environment. For these reasons, Davis's physical environment concept and dimensions were utilized for the current study.

\section{The Effects of Physical Environment: Work-Related Outcomes}

Historically, the physical environment has been studied as a predictor of various work-related outcomes, particularly employee behaviors. One of the earliest studies on this subject took place in 1958, when the famous Hawthorne studies were conducted. Elton Mayo sought to determine whether physical context (specifically, workspace lighting) affected factory workers' productivity (Oseland, 2009). Ultimately, this study had unexpected findings: worker behavior was altered because employees knew that they were being observed, not because of adjusted workspace lighting. However, this study 
served as an early foundation for the study of physical work environments. Since this influential experiment, researchers have tried to understand the effects workspaces have on employees, with a goal of creating the ideal physical work environment.

Another landmark event in the study of physical environment involves the openoffice redesign project at Chiat/Day, an American advertising company (Berger, 1999). In 1994, CEO Jay Chiat hired an artist named Gaetano Pesce to design a modern, stateof-the-art office for the employees in Manhattan, N.Y. Upon adoption of the project, Pesce removed all offices, creating an open space akin to an enormous coffee shop. A "staircase to nowhere" was installed in the building, and ping pong tables were placed in open areas (Berger, 1999). Both the artist and CEO believed this open office space would inspire creativity amongst the advertising employees. Unfortunately, the initial excitement about the unique office was fleeting, and employees soon reported extreme frustration. Common complaints included no individual assignment to a consistent spot within the workspace, a lack of privacy, floors that were an unsightly mix of bright hues, and plush sofas that were not conducive to desk work. The Chiat/Day story quickly became an infamous embarrassment for the company, with leaders scrambling to revert to a more traditional physical environment.

During the economic recession of the 2000s, organizations across the United States implemented extensive cost-cutting measures, some of which involved the physical environment. To save space and resources, many employers implemented an open-office design. Offices and cubicles were thus replaced with open, shared spaces to accommodate more employees in more compact workspaces. The savings were 
undeniable: "open-plan office space costs as much as $50 \%$ less per employee than more traditional office layouts, because of its smaller footprint and lower build-out costs" (Dizik, 2016). Employers have asserted that these redesigns were enacted to increase collaboration, communication, and other positive work behaviors, even though these claims were widely recognized as a transparent justification for cutting costs (Dizik, 2016).

Building on this foundation of research and practice, more recent researchers have sought to identify specific employee behavioral outcomes that are linked to the physical environment. Based on the results of subsequent research, the physical environment has been associated with a multitude of work-related behavioral outcomes, including perceived job performance, perceived productivity, and employee collaboration (Brennan, Chugh, \& Kline, 2002; Haynes, Suckley, \& Nunnington, 2017; Ricciotti et al., 2014). Results of these studies have been heavily referenced to identify ways in which companies can use space to maximize desirable behavioral outcomes.

Brennan et al. (2002) studied the effects of the physical work environment on perceived job performance. According to the authors, perceived job performance encapsulates an employee's assessment of his or her productivity, ability to work, and ability to focus. In this longitudinal study, perceived job performance was measured three times throughout a company's change from a traditional to open office: before the office redesign, four weeks after the redesign, and six months after the redesign. The researchers found that openness of the physical environment was negatively related to perceived job performance, such that moving from a traditional layout (cubicles and 
offices) towards an open floorplan (no private offices or cubicles) was associated with employees' feelings of a hindered ability to work, focus, and be productive. This outcome was observed both four weeks after the redesign and six months after the redesign.

Haynes et al. (2017) found that the office environment was related to employees' perceived productivity. The researchers also investigated ways in which age, gender, and office type affected employees' perceived productivity. In this study, perceived productivity was defined as an employee's assessment of his or her input and output in a work setting. The study involved a sample from a company with an open office, where noise, lack of privacy, and distractions were commonly reported problems. The researchers found that open-plan offices were associated with lower perceived productivity for male employees under the age of 35 compared to their older and female counterparts. The authors proposed that women were "more likely to see interruptions as a positive experience and would suggest a greater openness to work and social interactions within the office environment" (p. 131).

Another group of researchers observed a relationship between the physical environment and the employee behavioral outcome of collaboration (Ricciotti et al., 2014). In this observational study, collaboration was measured as work-related communication and civility amongst colleagues. The researchers collected data before and after a major redesign of a department within an academic medical center-the transition from closed, traditional offices to an open layout with clusters of tables in a large room. The researchers suggested that employee collaboration was related to the 
physical environment, such that an open office layout supported more communication and more frequent interaction between colleagues than traditional offices.

These research findings demonstrate that the physical environment is related to various employee outcomes, including job performance, productivity, and collaboration. Overall, these findings indicate that an open office layout is associated with lower perceived job performance, lower perceived productivity, and increased communication between colleagues. However, it is still unknown whether employee preferences affect outcomes of the physical environment. If employers consider employee preferences when designing a physical work environment, can more positive work outcomes be obtained? This leads to a prime research opportunity, a gap addressed by the current study: what predicts employee preferences for the physical environment? Establishing an answer to this question may help define specific physical environments that can result in desirable employee behavioral outcomes. Organizations across various industries can benefit from understanding predictors of preferences for physical work environments.

\section{Employee Preferences}

The idea of studying employee preferences is not completely novel. Some existing research has explored employee preferences, but not for the physical environment. For example, Vecchio and Boatwright (2002) conducted research on predictors of employee preferences for supervision style. The researchers found that education level and job tenure predicted supervision style preferences, such that highly educated employees who had been with an organization for a long period of time preferred less structured, less "directive" supervisors, compared to newer employees with less education who preferred 
more directive supervisors. Further, the authors found that gender predicted supervisor style preferences; more specifically, women preferred supervisors who ranked more highly in considerateness than men (Vecchio \& Boatwright, 2002). In another study, Stier and Lewin-Epstein (2003) related individual characteristics to employee preferences for working hours. The authors found that employees who were older, highly educated, and had higher income preferred to work fewer hours than their counterparts who were younger, less educated, and had lower incomes, respectively.

Upon consideration of the research related to employee preferences, a gap exists in terms of employee preferences specifically for the physical environment. Because earlier research suggests that organizations should consider employee preferences for workrelated variables such as supervisor style and working hours, there may be value in studying employee preferences for the physical environment. According to Luck (2003), there is a specific need to understand employee physical environment preferences, in that "the workspace needs of a person have a great impact on their ability to concentrate, produce, and be creative. Defining the needs of...workers can have a great impact on the future of work" (p. 20). Clearly, leaders of organizations can benefit from understanding employee preferences for the physical environment, prior to committing to a costly redesign of the physical environment.

\section{Predictors of Preferences for Physical Environment}

As previously mentioned, there is limited research on employee preferences for the physical environment. Oldham and Brass (1979) acknowledge a need to understand how and why employee preferences for the physical environment differ: “...it is possible that 
open-plan offices may be more appropriate for certain types of employees or certain types of organizations than for others" (p. 283). For leaders of an organization to harness the potential benefits of the physical workspace, it is important to understand what employees prefer. The definition of "physical environment preferences" employed in this study is synonymous with Luck's (2003) “workspace preferences": “an individual's choice of how [the] workspace is arranged that satisfies [his or her] personal needs" (p. 5).

Luck (2003) investigated two psychological predictors of preferences for the physical environment: locus of control and creativity. Locus of control was defined as "an individual's belief that, given a certain sequence of events, reinforcement will occur" (p. 6) and was divided into two categories: internal and external. An individual with an internal locus of control believes events occur because of his or her own behavior or personal characteristics. A person with an external locus of control believes fate, luck, and chance have more control over events than his or her own actions. Luck's second independent variable was creativity, defined as the "use of novel ideas that are applied appropriately to the task" (p. 5).

The author did not find a relationship between locus of control and physical environment preferences, nor between creativity and physical environment preferences. Although the researcher suggested that physical environment preferences could not be predicted with these variables, a few confounds should be considered. First, the participants in the study were all knowledge workers who scored highly on the creativity scale. This may suggest that the sample was not diverse enough to accurately represent 
the overall population of workers. Additionally, alternative predictor variables could still produce a different outcome.

Niemczyk and Ulrich (2009) considered a less psychological, but more demographic predictor: generation of the employee. Because individuals from different generations experience markedly different upbringings, the authors sought to identify work environment preferences of millennials (born between 1981 and 2000). Surveys were administered to 290 American employees in the aviation industry who were between the ages of 18 and 27. The survey was designed to assess generational differences in these employees' preferences for the physical environment. The authors found that employees in the sample preferred workspaces that were open and conducive to collaboration amongst coworkers. The authors suggested that these preferences differed from those of previous generations, who stereotypically strived for the "corner office," both a symbol of success and a place of privacy and autonomy. However, a major limitation of this study is that any contrast drawn between millennial employees and older generations was assumed - the participants surveyed were only members of the millennial generation. Ideally, future studies should address this by collecting and comparing data between different generations.

Although the existing research is valuable, it is limited in depth and breadth. There is a need to address more measurable predictors of preferences for physical environment than psychological predictors. Psychological predictors are interesting and useful yet are less often used by decision makers in organizations (compared to more tangible, objective predictors). Furthermore, wider populations should be studied than the aviation 
industry, which is exceptionally fast-paced and involves more time-sensitive decisions than the typical business setting (Niemczyk \& Ulrich, 2009). The purpose of the current study was to address this gap by studying measurable employee factors that predict preferences for physical environment in a more general office setting.

Job level and job family are easily measurable variables that pertain to employees within all organizations. Historically, both job level and job family have been examined as predictors of various outcomes, but they have been largely overlooked as predictors of preferences for the physical environment. The next sections present existing research that employs these variables as predictors of assorted outcomes.

\section{Job Level as a Predictor}

In the context of this study, job level refers to an employee's status as a manager or non-manager. "Manager" in this circumstance involves the supervision and responsibility of people (subordinates or direct-reports), as opposed to "management" of a project or program. A manager is typically an employee who has demonstrated adequate knowledge, skills, abilities, and trustworthiness to become responsible for supervising other employees. Essential skills possessed by managers include leadership, communication, collaboration, and critical thinking (Reh, 2017). Non-managers (frequently referred to as "individual contributors") are often entry-level employees, though they do not necessarily have lower skill levels than managers (non-managers could be subject matter experts who have chosen not to embark on the management track). Management positions, compared to non-management positions, have been associated with various work outcomes such as increased job satisfaction and job security 
(Armstrong-Stassen, 2001; Carlopio \& Gardner, 1995; Stellman, Klitzman, Gordon, \& Snow, 1987). Overall, job level not only determines the type of work performed, but also relates to various employee outcomes.

It is widely accepted that different job levels are associated with different levels of status and power: compared to non-management roles, management roles are typically associated with increased power (Paliadelis, 2013). Managers tend to possess larger, more private workspaces (typically closed offices). Accordingly, space and office equipment are resources that symbolize power in the work context. The relationship between work environment and managerial status suggest that managers and nonmanagers may have significantly different preferences for the physical workspace.

Based on the differences between managers and non-managers (particularly pertaining to status and power), it is proposed that employees from different job levels have different preferences for the physical environment at work. Perhaps managers prefer a more traditional office layout, which provides privacy and symbolizes status and power. Oldham and Brass (1979) suggest that management-level employees prefer more closed, private offices: "a move from conventional to an open-plan office should result in a substantial decline in autonomy...the absence of private offices and interior walls in open layouts increases the likelihood that supervisors and co-workers will interfere with or infringe upon an employee's discretion and freedom to work" (p. 271). Consequently, the current study examined the following research question: 
Research Question 1: How does job level relate to employee preferences for the three dimensions of the physical environment (physical structure, physical stimuli, and symbolic artifacts)?

\section{Job Family as a Predictor}

A job family is defined as "a group of jobs involving similar types of work and requiring similar training, skills, knowledge, and expertise" ("Compensation - Job Families," n.d.). Examples of job families include finance, human resources, and sales. Job families differ from one another in purpose, duty, responsibility, and process. Different job families often require varying levels of creativity, competitiveness, privacy, and collaboration. For example, a human resources employee is focused on supporting the company internally, whereas a sales employee is focused on increasing company revenue and providing external customer service.

As a result of distinctions between job families in skills and needs, perhaps employees within different job families have different preferences for the physical environment. Since human resources employees handle sensitive employee information, perhaps they prefer relatively private workspaces. On the contrary, sales employees may prefer to work in open environments, which enable chatter and competition. It is imaginable that an employer would tailor physical workspaces to job families, though in practice, employers do not typically do so.

Malone (1983) conducted an early study investigating job family as a predictor of preferences for neatness in the physical workspace. Neatness was defined as a level of tidiness that allowed the employee to find items when needed, and purposeful 
arrangement of items to remind the employee to perform certain tasks. The researcher conducted interviews and observations to gauge neatness levels amongst a small group of employees at an industrial research firm. The employees in the study were classified within different job families, including a purchasing agent (in the financial job family) and a physician (in the healthcare job family). These two positions differed in several ways, most noticeably, a purchasing agent typically worked alone with a routine schedule, whereas a physician worked with patients and more variety in day-to-day job duties.

Based on Malone's (1983) interviews and observations, the financial job family was associated with a preference for a neater office environment; on the other hand, the healthcare job family was associated with a preference for a less neat office environment. The author concluded that a relationship existed between job family and physical environment, such that individuals in the financial job family preferred neater office spaces, perhaps due to the routine and independent nature of their jobs. Conversely, individuals in the healthcare job family typically preferred a less neat workspace, due to the less predictable nature of their jobs. Although this study utilized a small sample of employees and job families, it contributes towards understanding the relationship between job family and preferences for the physical environment.

The second research question of the current study aims to elaborate upon Malone's (1983) research by examining the relationship between job family and preferences for the three dimensions of the physical environment. Although Malone examined employee preferences for neatness of the physical environment, the current study assessed 
employee preferences for all aspects of the physical environment: physical structure, physical stimuli, and symbolic artifacts. This study therefore proposed the following research question:

Research Question 2: How does job family relate to employee preferences for the three dimensions of the physical environment (physical structure, physical stimuli, and symbolic artifacts)?

\section{Purpose of the Current Study}

In conclusion, because job level and job family are directly observable and have been associated with various employee outcomes, they warrant further investigation as potential predictors of preferences for the physical environment. The purpose of the current study was to determine whether job level and job family predict employee preferences for the physical environment. More specifically, the present study sought to identify relationships between job level and job family and preferences for the three dimensions of physical environment: physical structure, physical stimuli, and symbolic artifacts.

The outcomes of this study may have important practical implications. If job level and job family are associated with employee preferences, then leaders of organizations can use this knowledge to strategically design environments to fulfill employee preferences. In turn, this could lead to the maximization of the positive employee outcomes previously mentioned (perceived job performance, perceived productivity, and collaboration). 


\section{Method}

\section{Participants}

Participants in this study included employees at a San Francisco Bay Area branch of a global medical technology company. Of the 506 employees who were invited to participate, 200 employees responded to the survey, a 39.5\% response rate. Each participant in the sample represented one of twelve different job families - the four job families with highest participation rates were included in the final sample. Therefore, the final sample consisted of a total of 157 employees.

Table 1 contains demographic data for the final sample of participants. Most participants fell into the $36-45$ years of age range (35\%). The sample was comprised of 53 women (33.8\%), 91 men (58\%), and 13 participants who declined to state their gender. Most participants were non-managers (75.2\%) versus managers (24.8\%), which is proportionate of the population within the company. The four job families in the final sample were engineering (59.9\%), finance (13.4\%), human resources (13.4\%), and marketing/communications (13.4\%).

\section{Procedure}

Data were collected online via Qualtrics, an online survey platform. Five-hundred and six employees at the company headquarters received an invitation to participate in the survey. Invitations were sent via email from an internal senior director-level employee. The email contained a brief description of the purpose of the project and a link to the survey. 
Table 1

Demographic Characteristics of Participants $(N=157)$

\begin{tabular}{clrr}
\hline Variable & & $n$ & \\
\hline \multirow{2}{*}{ Age } & & & \\
& $18-25$ & 5 & $3.2 \%$ \\
& $26-35$ & 36 & $22.9 \%$ \\
& $36-45$ & 55 & $35.0 \%$ \\
& $46-55$ & 34 & $21.7 \%$ \\
& $56-65$ & 21 & $13.4 \%$ \\
& $66-75$ & 4 & $2.5 \%$ \\
& Over 75 & 2 & $1.3 \%$
\end{tabular}

Gender

Male

$91 \quad 58 \%$

Female

$53 \quad 33.8 \%$

Decline to state

$13 \quad 8.2 \%$

Job family

$\begin{array}{lll}\text { Engineering } & 94 & 59.9 \% \\ \text { Finance } & 21 & 13.4 \% \\ \text { Human Resources } & 21 & 13.4 \% \\ \text { Marketing/Communications } & 21 & 13.4 \%\end{array}$

Job level

Manager

$39 \quad 24.8 \%$

Non-manager

118

$75.2 \%$

Employees who clicked the link were brought to an introductory page containing a consent notice. The consent notice emphasized the voluntary, anonymous nature of the survey. The notice also specified that choosing to click the "Next" button would indicate willingness to participate. An unsigned consent notice was deemed appropriate due to the anonymous nature of the project, and minimal risk involved. Participants were given the 
ability to stop and continue the survey freely (via the original survey link) and had the option to end the survey at any time.

\section{Measures}

Preferences for the physical environment. Preferences for the physical environment were measured with a scale composed of 18 items divided into three dimensions (physical structure, physical stimuli, and symbolic artifacts). Some of the items were adapted from Luck's (2003) Workspace Scales Survey (WSS), which contained 15 items assessing employee preferences for aspects of the physical workspace. Pertinent items from the WSS were retained and placed into one of the three sections. The remaining items were developed specifically for the purposes of the current study research. The scale utilized a five-point Likert scale from Strongly Disagree (1) to Strongly Agree (5).

The first six items in the instrument assessed preferences for physical structure, pertaining to placement of furnishings and walls. Sample items in this section include, "My preference is to work in a private office rather than a shared workspace" and "I like to work in an open office (shared space)." The reliability of this subscale was .69 , which indicates nearly acceptable subscale reliability.

Six items assessed preferences for physical stimuli in the environment. Items in this section pertained to noises, sights, and other stimuli that can attract employee attention and influence behavior. Sample items in this section are, "I do my best work in a quiet work environment" and "Clutter in my workspace is distracting to me." The reliability for this subscale was .72, indicating acceptable reliability. 
The remaining six items pertained to preferences for symbolic artifacts in the workspace, including colors, appearance, and symbolism of objects. Sample items in this section include, "It is important for the walls around me at work to be painted a nicelooking color" and "My workspace is symbolic of my status as an employee." Reliability for this subscale was .76 , denoting acceptable reliability.

Demographic variables. Four demographic variables were included in the instrument: age group, gender, job level, and job family. For the age group item, eight options were provided, including: "Under 18," "18-25," and "26-35." For the gender item, participants had the choice between "Male," "Female," and "Decline to State." Job level was presented with two options: "Manager" and "Non-Manager." Job family contained thirteen options, including "Engineering," "Finance," "Human Resources," and "Marketing/Communications." 


\section{Results}

\section{Descriptive Statistics}

Table 2 presents descriptive statistics for the three physical environment preferences dimensions. For all three dimensions, participant responses tended to remain close to the center (neutral) point. This implies that employees were fairly impartial in their

preferences for the physical environment at work; few items evoked strong agreement or disagreement.

Of the three dimensions, the physical structure scale had the most neutral mean $(M=3.19, S D=.69)$. Responses to the items in this dimension suggest that employees were neutral in their preferences for the layout of their workspaces. Within this dimension, employees most strongly agreed with the item, "It is important for my building to provide casual meeting spaces" $(M=4.02, S D=.97)$; the lowest level of agreement occurred on the item, "I like to work in an open office" $(M=2.25, S D=1.20)$. The descriptive results for this dimension showed that employees expected the work environment to accommodate spontaneous meetings, but they preferred not to work in open spaces.

The physical stimuli dimension resulted in the most agreeable responses from employees $(M=3.66, S D=.66)$. This suggests that employees in the sample had the strongest preferences pertaining to aspects of the work setting that attract attention and influence behavior. Within the dimension, employees showed strong agreement with the items, "I like to have my workspace well organized" $(M=3.98, S D=.87)$ and "I do my best work in a quiet work environment" $(M=3.97, S D=.98)$. Employees least agreed 
with the item, "I like when there is some background noise in my work environment" $(M=2.43, S D=1.05)$. These results indicate that employees in the sample preferred a well-organized and quiet work environment with limited ambient noise.

Employee responses tended to stay near the midpoint for the symbolic artifact dimension as well $(M=3.48, S D=.67)$. Consistent with the other dimensions, employees in the sample were relatively neutral in their preferences for the artistic design and style of the work environment. In this dimension, employees most preferred to have a pretty view while working $(M=3.96, S D=.88)$. Within the symbolic artifact dimension, responses were most neutral for the following item: "My workspace is symbolic of my status as an employee" $(M=2.99, S D=1.11)$. Based on these results, employees did not have strong preferences for the stylistic elements of their workspaces. 
Table 2

Descriptive Statistics, Preferences for the Physical Environment Scale Items $(N=157)$

\begin{tabular}{lrr}
\hline \multicolumn{1}{c}{ Item } & $M$ & $S D$ \\
\hline $\begin{array}{l}\text { Physical structure } \\
\text { 1. My preference is to work in a private office rather than a }\end{array}$ & $\mathbf{3 . 1 9}$ & $\mathbf{. 6 9}$ \\
$\quad$ shared workspace. & 3.91 & 1.16 \\
2. I like to work in an open office (shared space). & 2.25 & 1.20 \\
$\quad$ It is important for my building to provide casual meeting & 4.02 & .97 \\
3. spaces. & 3.38 & 1.07 \\
4. I prefer to work from home. & 2.71 & .97 \\
5. I like others to be able to see me while I work. & 3.17 & 1.17 \\
6. It is important to be able to speak with someone without first & &
\end{tabular}

Physical stimuli

$3.66 \quad .66$

7. I like when there is some background noise in my work environment.

$2.43 \quad 1.05$

8. I do my best work in a quiet work environment. $\quad 3.97 \quad 98$

9. Clutter in my workspace is distracting to me. $\quad 3.52 \quad 1.12$

$\begin{array}{llll}\text { 10. I like to have my workspace well organized. } & 3.98 & .87\end{array}$

11. I need control of the sights and sounds around me while I am $\quad 3.59 \quad .97$ working.

$2.65 \quad 1.10$

12. At work, I enjoy hearing others interact with each other.

$3.48 \quad .67$

13. It is important for the walls around me at work to be painted a
13 nice-looking color.

$3.75 \quad .91$

14. I like to personalize my work environment with pictures, artwork, or other décor.

$3.70 \quad 1.02$

$\begin{array}{llrr}\text { 15. I prefer to have a pretty view while I am working. } & 3.96 & .88 \\ \text { 16. My workspace is symbolic of my status as an employee. } & 2.99 & 1.11\end{array}$

17. It is important to have my company display artwork in the work environment.

$3.25 \quad .94$

18. If I could change the color scheme of my current workspace, I would. 


\section{Pearson Correlations}

Pearson correlations were employed to assess the extent to which the three dimensions of the physical environment were correlated with one another. Correlations are displayed in Table 3. Based on the analysis, employee preferences for physical structure were positively correlated with employee preferences for physical stimuli $(r=.42, p<.001)$. This indicates that employees who preferred more privacy in the layout of their workspace also preferred a more orderly and quiet workspace. Although these dimensions are correlated, they are still distinct. The symbolic artifact dimension was not correlated with the other dimensions, suggesting the employees' stylistic preferences were not closely associated with preferences for layout and stimuli.

Table 3

Pearson Correlations and Cronbach's Alphas

\begin{tabular}{llll}
\hline Dimension & 1 & 2 & 3 \\
\hline 1. Physical structure & $(.69)$ & & \\
2. Physical stimuli & $.42^{* * *}$ & $(.72)$ \\
3. Symbolic artifacts & -.07 & .14 & $(.76)$ \\
& & & \\
Note. Reliability coefficients are in parentheses along the diagonal. $N=157 .{ }^{*} \mathrm{p}<.05$, \\
$* * \mathrm{p}<.01, * * * \mathrm{p}<.001$.
\end{tabular}




\section{Job Level Differences}

The next analyses addressed the first research question: how does job level relate to employee preferences for the three dimensions of the physical environment (physical structure, physical stimuli, and symbolic artifacts)? As such, t-tests were utilized to determine whether there was a difference in employee preferences for each dimension of the physical environment based on job level (manager versus non-manager). Table 4 shows the results of these analyses.

The first analysis revealed that there was no significant difference between managers $(M=3.13, S D=.70)$ and non-managers $(M=3.21, S D=.68)$ on preferences for physical structure, $t(155)=-.61, p>.05$. Similarly, there was no significant difference between managers $(M=3.51, S D=.61)$ and non-managers $(M=3.47, S D=.70)$ on preferences for the symbolic artifacts dimension, $t(155)=.35, p>.05$. These results show that employee preferences for workspace layout and symbolic/aesthetic style were not different for mangers versus non-managers. One t-test did find a significant difference between managers and non-managers on preferences for physical stimuli; $t(155)=-2.23$, $p<.05$. This result suggests that non-managers $(M=3.73, S D=.67)$ more strongly preferred cleaner and quieter workspaces than managers $(M=3.46, S D=.58)$.

In summary, employees did not differ in their preferences for physical structure and symbolic artifacts, regardless of whether they were managers or non-managers.

However, managers and non-managers did differ in their preferences for physical stimuli such that non-managers more strongly preferred clean and quiet spaces than managers. 
Table 4

Results of t-Test and Descriptive Statistics for Physical Environment Preferences by Job Level

\begin{tabular}{lcccccccc}
\hline & \multicolumn{7}{c}{ Job level } \\
\cline { 2 - 4 } \cline { 6 - 7 } & $\mathrm{M}$ & $\mathrm{SD}$ & $\mathrm{n}$ & & $\mathrm{M}$ & $\mathrm{SD}$ & $\mathrm{n}$ & $\mathrm{t}$ \\
\hline $\begin{array}{l}\text { Physical } \\
\text { structure }\end{array}$ & 3.13 & 70 & 39 & & 3.21 & .68 & 118 & -.61 \\
$\begin{array}{l}\text { Physical stimuli } \\
\text { Symbolic }\end{array}$ & 3.46 & .58 & 39 & & 3.73 & .67 & 118 & $-2.23 *$ \\
artifacts & 3.51 & .61 & 39 & & 3.47 & .70 & 118 & .35 \\
\hline Note. ${ }^{*} \mathrm{p}<.05, * * \mathrm{p}<.01, * * * \mathrm{p}<.001$. & & & & &
\end{tabular}

\section{Job Family Differences}

The purpose of the next set of analyses was to address the second research question: How does job family relate to employee preferences for the three dimensions of the physical environment (physical structure, physical stimuli, and symbolic artifacts)? Three one-way analyses of variance (ANOVAs) were run to determine whether statistically significant differences exist between employee preferences for the physical environment based on job family (engineering, finance, human resources, and marketing/communications).

As seen in Table 5, for the physical structure dimension, there was no significant difference between employee preferences based on job family, $F(3,153)=1.33, p>.05$. Similarly, results of the one-way ANOVA showed that employees of different job families did not differ significantly on their preferences for physical stimuli, $F(3,153)=1.06, p>.05$. Lastly, the relationship between job family and employee preferences for symbolic artifacts was not statistically significant, $F(3,153)=1.22$, $p>.05$. 
Based on the results of these ANOVAs, an employee's preference for physical workspace arrangement, sights, sounds, and aesthetics were not related to his or her belonging in engineering, finance, human resources, and marketing/communications. To summarize, in the context of the second research question, there was no evidence that employee preferences for the physical workspace varied by type of work, duties, and responsibilities.

Table 5

Means, Standard Deviations, and One-Way Analyses of Variance (ANOVAs) for Effects of Job Family on Preferences for the Physical Environment

\begin{tabular}{|c|c|c|c|c|c|c|c|c|c|}
\hline \multirow[t]{2}{*}{ Variable } & \multicolumn{2}{|c|}{ Engineering } & \multicolumn{2}{|c|}{ Finance } & \multicolumn{2}{|c|}{$\begin{array}{c}\text { Human } \\
\text { Resources }\end{array}$} & \multicolumn{2}{|c|}{$\begin{array}{c}\text { Marketing/ } \\
\text { Communications } \\
\end{array}$} & \multirow{2}{*}{$\begin{array}{l}\text { ANOVA } \\
\mathrm{F}(3,153)\end{array}$} \\
\hline & M & SD & M & SD & M & $\mathrm{SD}$ & M & SD & \\
\hline $\begin{array}{l}\text { Physical } \\
\text { structure }\end{array}$ & 3.24 & .71 & 3.33 & .74 & 2.98 & .66 & 3.06 & .53 & 1.33 \\
\hline $\begin{array}{l}\text { Physical } \\
\text { stimuli }\end{array}$ & 3.69 & .67 & 3.82 & .80 & 3.58 & .52 & 3.48 & .53 & 1.06 \\
\hline $\begin{array}{l}\text { Symbolic } \\
\text { artifacts }\end{array}$ & 3.48 & .74 & 3.29 & .67 & 3.68 & .59 & 3.48 & .39 & 1.22 \\
\hline
\end{tabular}




\section{Moderating Effects of Gender and Age}

A series of two-way ANOVAs were conducted to identify potential moderators of the relationships between job level/job family and preferences for the physical environment. Gender and age group are the moderating variables considered. To ensure groups were large enough to be analyzed, two variables were reduced into modified groups: job family was condensed into engineering versus non-engineering, and age group was condensed into "below 36 years old," "between 36 and 45 years old," and "over 46 years old." For the moderating variable of gender, individuals who selected "decline to state" $(n=13)$ were removed from the analysis. The following analyses investigated gender as a moderator, and the second set of analyses investigated age as a moderator.

Job level and gender. The first analyses assessed whether employee preferences for the physical environment varied within job level based on gender. As seen in Table 6, there were no significant differences between managers and non-managers based on gender for the first two dimensions (physical structure and physical stimuli). This means that managers and non-managers had similar preferences for workspace layout, sights, and sounds, regardless of whether they were male or female. However, there was a statistically significant interaction between gender and job level for the third dimension, preferences for symbolic artifacts, $F(1,140)=5.03, p<.05$. The means listed in Table 7 and depicted in Figure 1 show that job level relates to employee preferences for symbolic artifacts, but only for women, such that female managers $(M=3.88, S D=.59)$ expressed a stronger preference for an appealing, stylistic workspace than female non-managers $(M=3.40, S D=.64)$. In contrast, male managers' preferences for symbolic artifacts 
$(M=3.35, S D=.56)$ did not differ significantly from male non-managers' preferences $(M=3.47, S D=.73)$.

In summary, female managers had stronger preferences for the style and appearance of a workspace than female non-managers, yet the preferences of male managers and non-managers were similar to one another. In terms of the physical structure and physical stimuli dimensions, employee preferences did not differ, regardless of gender and job level. 
Table 6

Two-Way ANOVA for Preferences for the Physical Environment as a Function of Job Level by Gender

Physical structure

\begin{tabular}{lcccc}
\multicolumn{1}{c}{ Source } & SS & $d f$ & MS & F \\
\hline Job level & .52 & 1 & .52 & 1.15 \\
Gender & .61 & 1 & .61 & 1.33 \\
Job level x Gender & .88 & 1 & .88 & 1.94 \\
Error & 63.77 & 140 & .46 & \\
\hline
\end{tabular}

Physical stimuli

\begin{tabular}{lcccc}
\multicolumn{1}{c}{ Source } & SS & $d f$ & MS & F \\
\hline Job level & .93 & 1 & .93 & 2.34 \\
Gender & .85 & 1 & .85 & 2.15 \\
Job level x Gender & .76 & 1 & .76 & 1.93 \\
Error & 55.33 & 140 & .40 & \\
\hline
\end{tabular}

Symbolic artifacts

\begin{tabular}{lcccc}
\multicolumn{1}{c}{ Source } & SS & $d f$ & MS & F \\
\hline Job level & .89 & 1 & .89 & 2.00 \\
Gender & 1.32 & 1 & 1.32 & 2.96 \\
Job level x Gender & 2.24 & 1 & 2.24 & $5.03^{*}$ \\
Error & 62.50 & 140 & .45 & \\
\hline
\end{tabular}

$* \mathrm{p}<.05$ 
Table 7

Means and Standard Deviations for Preferences for the Physical Environment as a Function of Job Level and Gender

Physical structure

\begin{tabular}{lccc} 
& \multicolumn{2}{c}{ Gender } & \\
& $\begin{array}{c}\text { Male } \\
(n=91)\end{array}$ & $\begin{array}{c}\text { Female } \\
(n=53)\end{array}$ & Total \\
\cline { 2 - 3 } $\begin{array}{l}\text { Manager } \\
(n=36)\end{array}$ & 3.20 & 2.86 & 3.08 \\
& $(.69)$ & $(.61)$ & $(.68)$
\end{tabular}

Job level

\begin{tabular}{cccc} 
Non-manager & 3.16 & 3.19 & 3.17 \\
$(n=108)$ & $(.63)$ & $(.75)$ & $(.68)$ \\
\cline { 2 - 3 } Total & 3.17 & 3.11 & \\
& $(.64)$ & $(.73)$ &
\end{tabular}

Physical stimuli

\begin{tabular}{cccc} 
& $\begin{array}{c}\text { Male } \\
(n=91)\end{array}$ & $\begin{array}{c}\text { Female } \\
(n=53)\end{array}$ & Total \\
\cline { 2 - 3 } $\begin{array}{ccc}\text { Manager } \\
(n=36)\end{array}$ & 3.47 & 3.46 & 3.47 \\
& $(.61)$ & $(.54)$ &
\end{tabular}

Job level

\begin{tabular}{cccc} 
Non- & 3.84 & 3.48 & 3.71 \\
Manager & $(.63)$ & $(.66)$ & $(.66)$ \\
$(n=108)$ & 3.75 & 3.47 & \\
\cline { 2 - 3 } Total & $(.64)$ & $(.63)$ &
\end{tabular}

Symbolic artifacts

\begin{tabular}{cccc} 
& $\begin{array}{c}\text { Male } \\
(n=91)\end{array}$ & $\begin{array}{c}\text { Female } \\
(n=53)\end{array}$ & Total \\
\cline { 2 - 3 } $\begin{array}{c}\text { Manager } \\
(n=36)\end{array}$ & 3.35 & 3.88 & 3.55 \\
& $(.56)$ & $(.59)$ & $(.62)$
\end{tabular}

Job level

\begin{tabular}{cccc}
$\begin{array}{c}\text { Non-Manager } \\
(n=108)\end{array}$ & 3.47 & 3.40 & 3.44 \\
\cline { 2 - 3 } Total & $(.73)$ & $(.64)$ & $(.69)$ \\
& 3.44 & 3.52 & \\
& $(.69)$ & $(.66)$
\end{tabular}




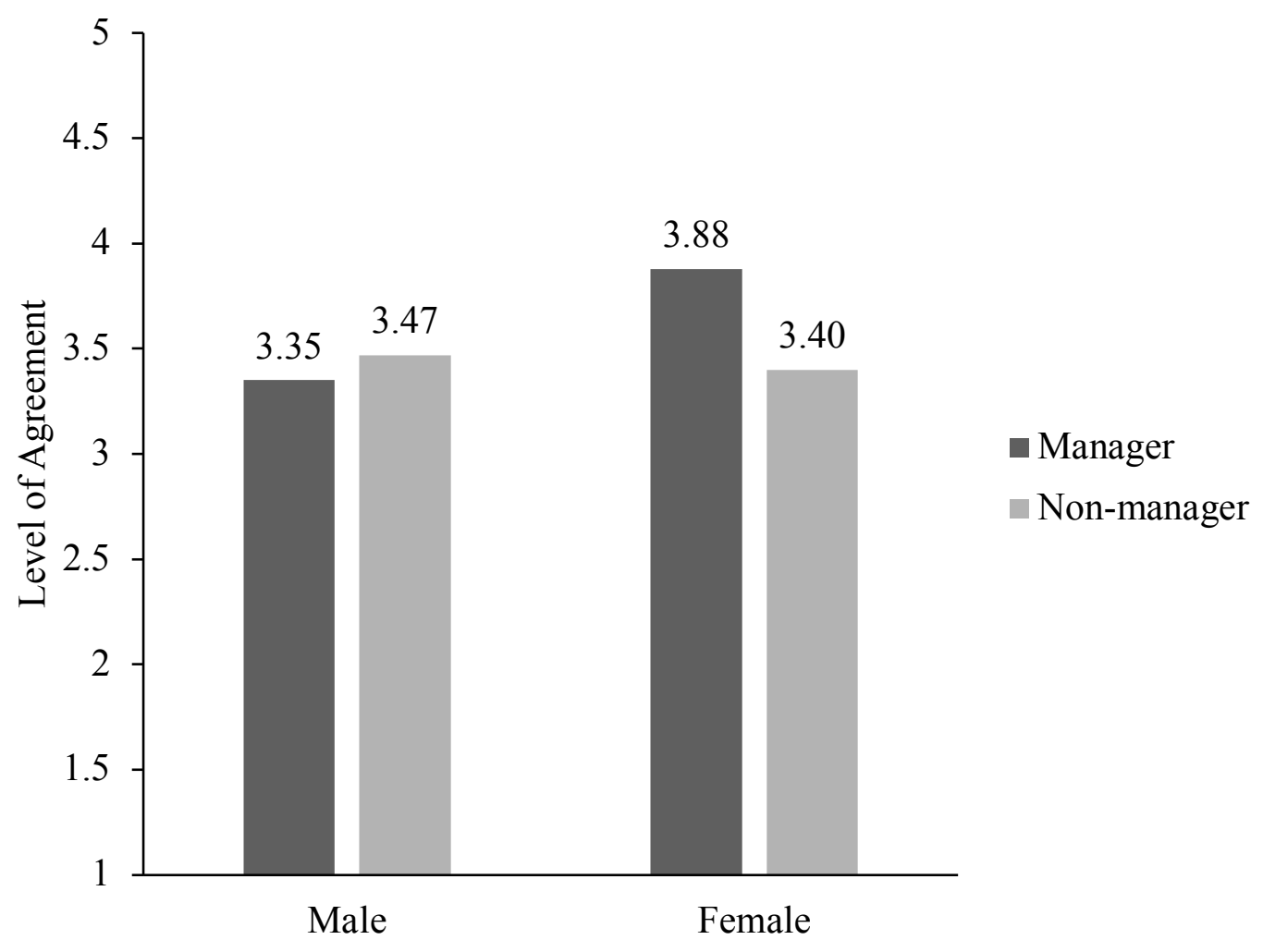

Figure 1. Mean scores for male and female managers and non-managers on preferences for symbolic artifacts. 
Job family and gender. As seen in Table 8, the next analyses tested the interaction between job family (engineering versus non-engineering) and gender. For the physical structure dimension, the interaction between job family and gender significantly contributed to employee preferences for the physical workspace, $F(1,140)=4.14$, $p<.05$. More specifically, female engineers $(M=3.36, S D=.79)$ more strongly preferred a closed, private workspace than female non-engineers $(M=3.00, S D=.68$; see means listed in Table 9). However, male engineers $(M=3.13, S D=.67)$ and non-engineers $(M=3.29, S D=.56)$ did not differ significantly from one another in their preferences for physical structure. These findings for the physical structure dimension are depicted in Figure 2.

For the physical stimuli dimension, the interaction between job family and gender was significant, $F(1,140)=4.04, p<.05$. As shown in Table 9, female engineers more strongly preferred a quiet workspace with few distractions than female non-engineers $(M=3.65, S D=.61$ and $M=3.41, S D=.63$, respectively). Males differed in the opposite direction: male engineers $(M=3.68, S D=.67)$ less strongly preferred a quiet workspace with few distractions than male non-engineers $(M=3.93, S D=.52)$. Means for this dimension are illustrated in Figure 3.

For symbolic artifacts, the third dimension, gender did not significantly moderate the relationship between job family and preferences for the style/appearance of a workspace $F(1,140)=.02, p>.05$. This suggests that engineers and non-engineers did not differ in their preferences for the style and aesthetic appeal of the workspace, based on their genders. 
Table 8

Two-Way ANOVA for Preferences for the Physical Environment as a Function of Job Family by Gender

Physical structure

\begin{tabular}{lcccc}
\multicolumn{1}{c}{ Source } & SS & $d f$ & MS & F \\
\hline Job family & .28 & 1 & .28 & .63 \\
Gender & .02 & 1 & .02 & .05 \\
Job family x Gender & 1.86 & 1 & 1.86 & $4.14^{*}$ \\
Error & 63.00 & 140 & .45 & \\
\hline
\end{tabular}

Physical stimuli

\begin{tabular}{lcccc}
\multicolumn{1}{c}{ Source } & SS & $d f$ & MS & F \\
\hline Job family & .00 & 1 & .00 & .00 \\
Gender & 2.16 & 1 & 2.16 & 5.40 \\
Job family x Gender & 1.62 & 1 & 1.62 & $4.04^{*}$ \\
Error & 55.96 & 140 & .40 & \\
\hline
\end{tabular}

Symbolic artifacts

\begin{tabular}{lcccc}
\multicolumn{1}{c}{ Source } & SS & $d f$ & MS & F \\
\hline Job family & .00 & 1 & .00 & .00 \\
Gender & .17 & 1 & .17 & .36 \\
Job family x Gender & .01 & 1 & .01 & .02 \\
Error & 65.04 & 140 & .47 & \\
\hline
\end{tabular}

$* \mathrm{p}<.05$ 
Table 9

Means and Standard Deviations for Preferences for the Physical Environment as a Function of Job Family and Gender

Physical structure

\begin{tabular}{cccc} 
& \multicolumn{2}{c}{ Gender } & \\
& $\begin{array}{c}\text { Male } \\
(n=91)\end{array}$ & $\begin{array}{c}\text { Female } \\
(n=53)\end{array}$ & Total \\
\cline { 2 - 3 } $\begin{array}{ccc}\text { Engineer } \\
(n=84)\end{array}$ & 3.13 & 3.36 & 3.17 \\
& $(.67)$ & $(.79)$ & $(.69)$
\end{tabular}

Job family

\begin{tabular}{cccc}
$\begin{array}{c}\text { Non-Engineer } \\
(n=60)\end{array}$ & 3.29 & 3.00 & 3.11 \\
\cline { 2 - 3 } Total & $(.56)$ & $(.68)$ & \\
& 3.17 & 3.11 \\
& $(.64)$ & $(.73)$
\end{tabular}

Physical stimuli

\begin{tabular}{lccc} 
& $\begin{array}{c}\text { Male } \\
(n=91)\end{array}$ & $\begin{array}{c}\text { Female } \\
(n=53)\end{array}$ & Total \\
\cline { 2 - 3 } $\begin{array}{ccc}\text { Engineer } \\
(n=84)\end{array}$ & 3.68 & 3.65 & 3.68 \\
& $(.67)$ & $(.61)$ & $(.66)$
\end{tabular}

Job family

\begin{tabular}{cccc}
$\begin{array}{c}\text { Non-Engineer } \\
(n=60)\end{array}$ & 3.93 & 3.41 & 3.60 \\
\cline { 2 - 3 } & $(.52)$ & $(.63)$ & $(.64)$ \\
Total & 3.75 & 3.47 \\
& $(.64)$ & $(.63)$
\end{tabular}

Symbolic artifacts

Job family

\begin{tabular}{cccc} 
& \multicolumn{2}{c}{ Symbolic artifacts } & \\
& $\begin{array}{c}\text { Male } \\
(n=91)\end{array}$ & $\begin{array}{c}\text { Female } \\
(n=53)\end{array}$ & Total \\
\cline { 2 - 3 } $\begin{array}{c}\text { Engineer } \\
(n=84)\end{array}$ & 3.43 & 3.45 & 3.44 \\
& $(.75)$ & $(.46)$ & $(.69)$ \\
Non-Engineer & 3.53 & & \\
$(n=60)$ & $(.66)$ & 3.51 & 3.52 \\
Total & 3.45 & $(.66)$ & \\
\cline { 2 - 3 } & $(.73)$ & 3.49 & \\
& & $(.59)$ &
\end{tabular}




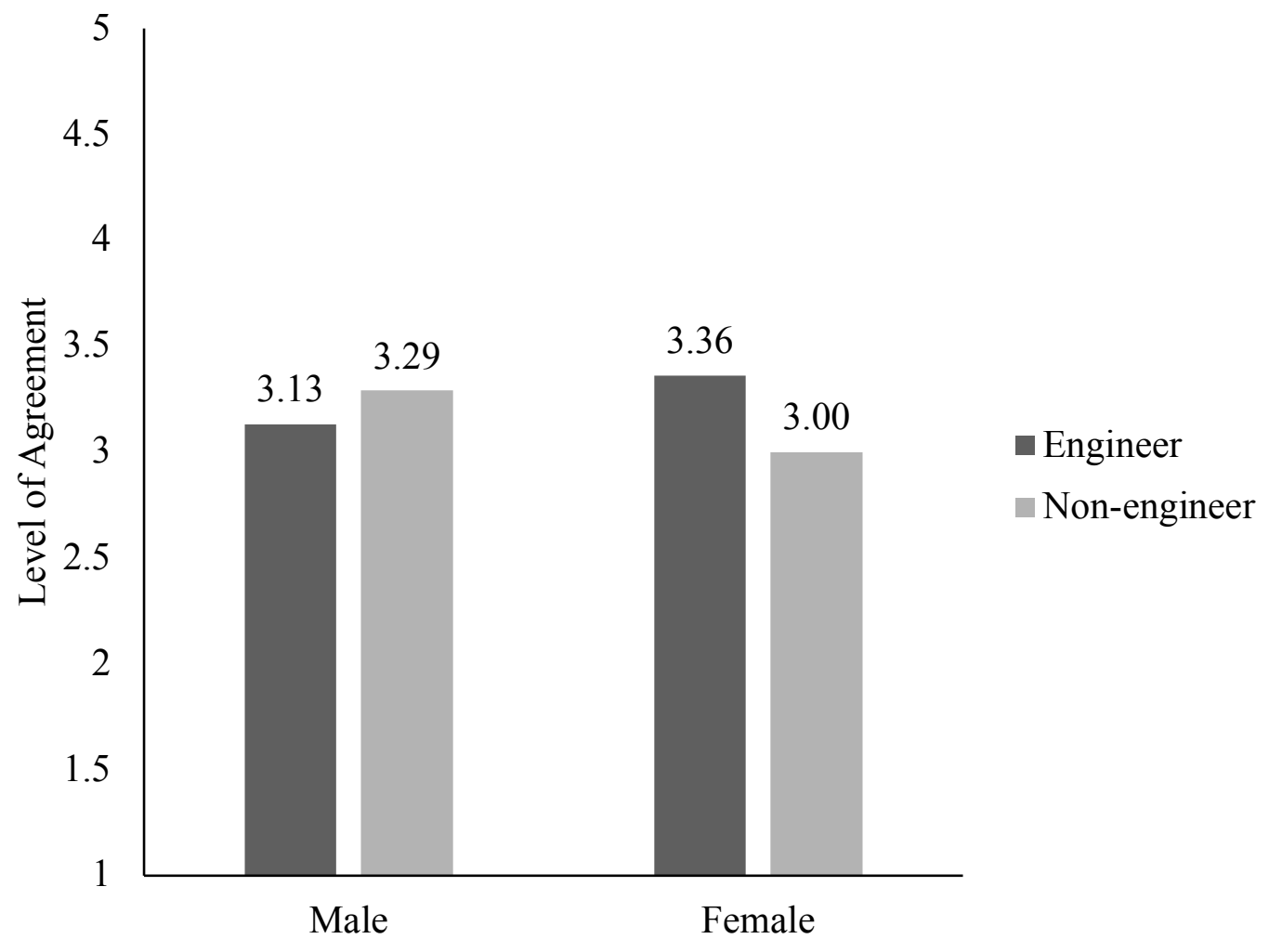

Figure 2. Mean scores for male and female engineers and non-engineers on preferences for physical structure. 


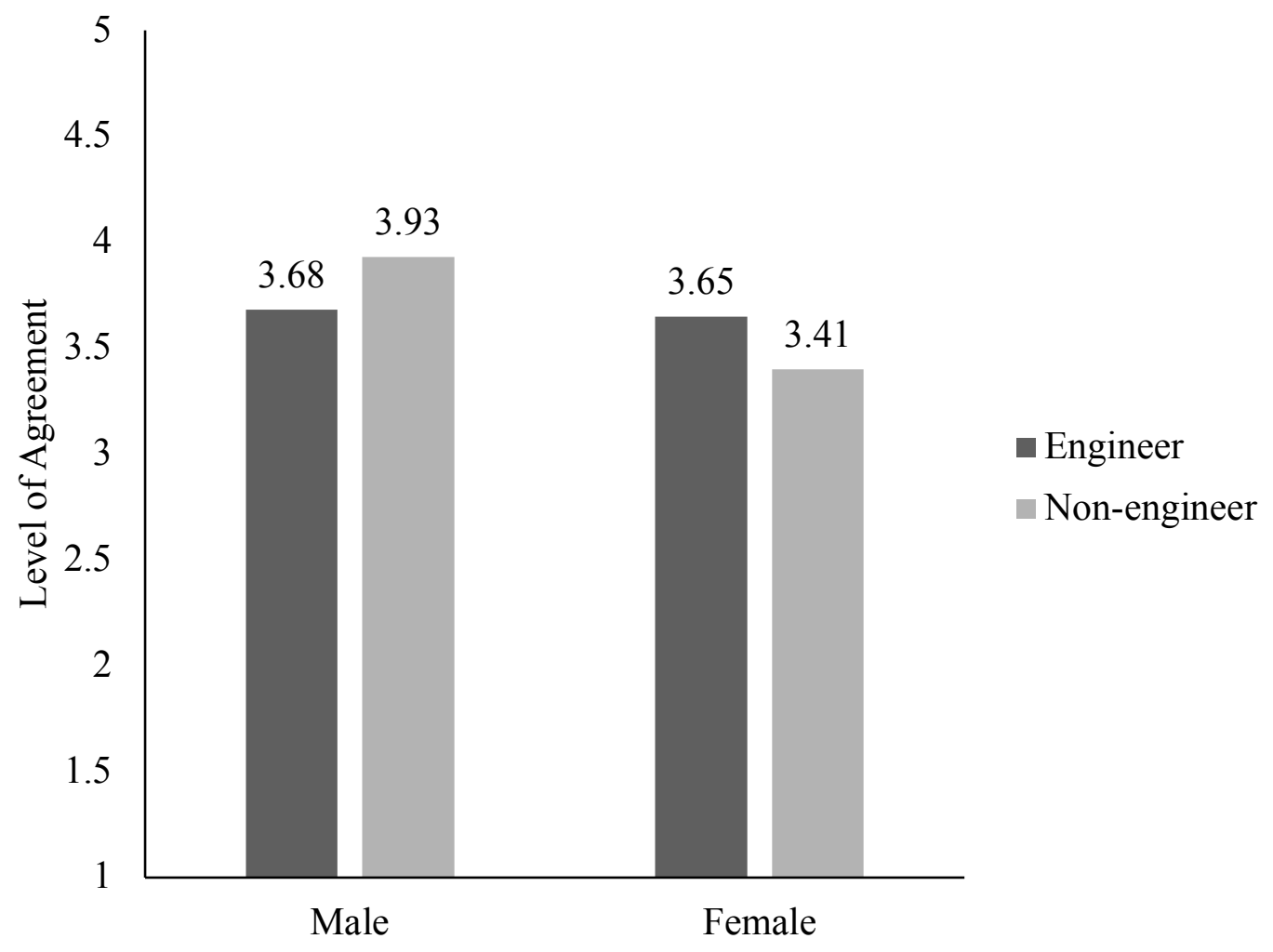

Figure 3. Mean scores for male and female engineers and non-engineers on preferences for physical stimuli.

In summary, two significant job family by gender interactions were found. First, female engineers more strongly preferred a closed and private workspace than female non-engineers. Second, female engineers more strongly preferred a workspace with fewer distractions than female non-engineers, whereas male engineers had less strong preferences for levels of distraction than male non-engineers. Engineers and nonengineers did not differ in their preferences for the style and aesthetic appeal of the workspace as a function of gender.

Job level and age. Two-way ANOVAs were employed to assess whether employee preferences for the physical environment varied within job level as a function of age group (below 36 years old, between 36 and 45 years old, and over 46 years old). Results 
and means from these analyses are listed in Tables 10 and 11. None of the findings are significant, implying that employee preferences for the physical workspace did not differ by age group within job levels.

Job family and age. The final two-way ANOVAs tested the interaction between age group (below 36 years old, between 36 and 45 years old, and over 46 years old) and job family (engineering versus non-engineering). Tables 12 and 13 present results of these analyses. Again, the results of these analyses were not significant-employee workspace preferences did not vary within job families based on age group. 
Table 10

Two-Way ANOVA for Preferences for the Physical Environment as a Function of Job Level by Age

Physical structure

\begin{tabular}{lcccc}
\multicolumn{1}{c}{ Source } & SS & $d f$ & MS & F \\
\hline Job level & .06 & 1 & .06 & .13 \\
Age & .83 & 2 & .41 & .89 \\
Job level x Age & 2.09 & 2 & 1.05 & 2.23 \\
Error & 70.62 & 151 & .49 & \\
\hline
\end{tabular}

Physical stimuli

\begin{tabular}{lcccc}
\multicolumn{1}{c}{ Source } & SS & $d f$ & MS & F \\
\hline Job level & 1.44 & 1 & 1.44 & 3.43 \\
Age & 1.58 & 2 & .79 & 1.88 \\
Job level x Age & 1.03 & 2 & .51 & .30 \\
Error & 63.37 & 151 & .42 & \\
\hline
\end{tabular}

Symbolic artifacts

\begin{tabular}{lcccc}
\multicolumn{1}{c}{ Source } & SS & $d f$ & MS & F \\
\hline Job level & .01 & 1 & .01 & .03 \\
Age & .25 & 2 & .13 & .28 \\
Job level x Age & 1.29 & 2 & .64 & 1.40 \\
Error & 69.33 & 151 & .46 & \\
\hline
\end{tabular}

$* \mathrm{p}<.05$ 
Table 11

Means and Standard Deviations for Preferences for the Physical Environment as a Function of Job Level and Age

\begin{tabular}{|c|c|c|c|c|}
\hline & & $\begin{array}{l}\text { ysical structure } \\
\text { Age group }\end{array}$ & & \\
\hline & $\begin{array}{c}<36 \text { years } \\
(n=41)\end{array}$ & $\begin{array}{c}36-45 \text { years } \\
(n=55)\end{array}$ & $\begin{array}{c}>46 \text { years } \\
(n=61)\end{array}$ & Total \\
\hline $\begin{array}{c}\text { Manager } \\
(n=39)\end{array}$ & $\begin{array}{l}3.18 \\
(.60)\end{array}$ & $\begin{array}{l}2.91 \\
(.69)\end{array}$ & $\begin{array}{l}3.37 \\
(.74)\end{array}$ & $\begin{array}{l}3.13 \\
(.70)\end{array}$ \\
\hline
\end{tabular}

Job level

\begin{tabular}{cccc}
$\begin{array}{c}\text { Non-manager } \\
(n=118)\end{array}$ & 3.07 & 3.32 & 3.22 \\
& $(.66)$ & $(.70)$ & $(.68)$ \\
\cline { 2 - 4 } Total & 3.10 & 3.20 & 3.25 \\
& $(.72)$ & $(.72)$ & $(.69)$
\end{tabular}

Physical stimuli

\begin{tabular}{ccccc} 
& $\begin{array}{c}<36 \text { years } \\
(n=41)\end{array}$ & $\begin{array}{c}36-45 \text { years } \\
(n=55)\end{array}$ & $\begin{array}{c}>46 \text { years } \\
(n=61)\end{array}$ & Total \\
\cline { 2 - 4 } $\begin{array}{c}\text { Manager } \\
(n=39)\end{array}$ & 3.72 & 3.22 & 3.56 & 3.46 \\
& $(.39)$ & $(.75)$ & $(.32)$ & $(.58)$
\end{tabular}

Job level

\begin{tabular}{cccc}
$\begin{array}{c}\text { Non-manager } \\
(n=118)\end{array}$ & 3.72 & 3.69 & 3.77 \\
\multirow{2}{*}{ Total } & $(.68)$ & $(.66)$ & $(.69)$ \\
\cline { 2 - 4 } & 3.72 & 3.55 & 3.72 \\
& $(.62)$ & $(.71)$ & $(.63)$
\end{tabular}

3.73

Symbolic artifacts

\begin{tabular}{ccccc} 
& $\begin{array}{c}<36 \text { years } \\
(n=41)\end{array}$ & $\begin{array}{c}36-45 \text { years } \\
(n=55)\end{array}$ & $\begin{array}{c}>46 \text { years } \\
(n=61)\end{array}$ & Total \\
\cline { 2 - 4 } $\begin{array}{c}\text { Manager } \\
(n=39)\end{array}$ & 3.37 & 3.46 & 3.70 & 3.51 \\
& $(.37)$ & $(.73)$ & $(.60)$ & $(.61)$
\end{tabular}

Job level

\begin{tabular}{cccc} 
Non-manager & 3.62 & 3.42 & 3.41 \\
$(n=118)$ & $(.54)$ & $(.74)$ & $(.74)$ \\
\cline { 2 - 4 } Total & 3.56 & 3.43 & 3.47 \\
& $(.51)$ & $(.73)$ & $(.72)$
\end{tabular}


Table 12

Two-Way ANOVA for Preferences for the Physical Environment as a Function of Job Family by Age

Physical structure

\begin{tabular}{lcccc}
\multicolumn{1}{c}{ Source } & SS & $d f$ & MS & F \\
\hline Job family & .57 & 1 & .57 & 1.21 \\
Age & .68 & 2 & .34 & .72 \\
Job family x Age & .44 & 2 & .22 & .46 \\
Error & 71.89 & 151 & .48 & \\
\hline
\end{tabular}

Physical stimuli

\begin{tabular}{lcccc}
\multicolumn{1}{c}{ Source } & SS & $d f$ & MS & F \\
\hline Job family & .17 & 1 & .17 & .40 \\
Age & .71 & 2 & .36 & .82 \\
Job family x Age & .58 & 2 & .29 & .67 \\
Error & 65.48 & 151 & .43 & \\
\hline
\end{tabular}

Symbolic artifacts

\begin{tabular}{lcccc}
\multicolumn{1}{c}{ Source } & SS & $d f$ & MS & F \\
\hline Job family & .00 & 1 & .00 & .00 \\
Age & .27 & 2 & .13 & .28 \\
Job family x Age & .35 & 2 & .17 & .37 \\
Error & 70.33 & 151 & .47 & \\
\hline
\end{tabular}

$* \mathrm{p}<.05$ 
Table 13

Means and Standard Deviations for Preferences for the Physical Environment as a Function of Job Family and Age

\begin{tabular}{ccccc}
\multicolumn{5}{c}{ Physical structure } \\
& Age group & \\
& $<36$ years & $36-45$ years & $>46$ years & Total \\
& $(n=41)$ & $(n=55)$ & $(n=61)$ & 3.24 \\
Engr & 3.20 & 3.19 & 3.32 & $(.71)$
\end{tabular}

Job family

\begin{tabular}{cccc}
$\begin{array}{c}\text { Non-engr } \\
(n=63)\end{array}$ & 2.95 & 3.21 & 3.17 \\
& $(.64)$ & $(.57)$ & $(.72)$ \\
\cline { 2 - 4 } Total & 3.10 & 3.20 & 3.25 \\
& $(.64)$ & $(.72)$ & $(.69)$
\end{tabular}

3.12

Physical stimuli

\begin{tabular}{ccccc} 
& $\begin{array}{c}<6 \text { years } \\
(n=41)\end{array}$ & $\begin{array}{c}36-45 \text { years } \\
(n=55)\end{array}$ & $\begin{array}{c}>46 \text { years } \\
(n=61)\end{array}$ & Total \\
\cline { 2 - 4 } Engr & 3.76 & 3.52 & 3.81 & 3.69 \\
$(n=94)$ & $(.64)$ & $(.77)$ & $(.55)$ & $(.67)$
\end{tabular}

Job family

\begin{tabular}{cccc} 
Non-engr & 3.67 & 3.61 & 3.61 \\
$(n=63)$ & $(.60)$ & $(.59)$ & $(.71)$ \\
\cline { 2 - 4 } Total & 3.72 & 3.55 & 3.72 \\
& $(.62)$ & $(.71)$ & $(.63)$
\end{tabular}

3.63

Symbolic artifacts

\begin{tabular}{ccccc} 
& $\begin{array}{c}<6 \text { years } \\
(n=41)\end{array}$ & $\begin{array}{c}36-45 \text { years } \\
(n=55)\end{array}$ & $\begin{array}{c}>46 \text { years } \\
(n=61)\end{array}$ & Total \\
\cline { 2 - 4 } Engr & 3.58 & 3.39 & 3.50 & 3.48 \\
$(n=94)$ & $(.52)$ & $(.83)$ & $(.76)$ & $(.74)$
\end{tabular}

Job family

\begin{tabular}{llll}
$\begin{array}{l}\text { Non-engr } \\
(n=63)\end{array}$ & 3.53 & 3.53 & 3.43 \\
\cline { 2 - 4 } Total & $(.51)$ & $(.47)$ & $(.68)$ \\
\cline { 2 - 4 } & 3.56 & 3.43 & 3.47 \\
& $(.51)$ & $(.73)$ & $(.72)$
\end{tabular}

3.48 


\section{Discussion}

The goal of this study was to bridge a gap in the existing research concerning physical work environments. Existing research focused primarily on outcomes of the physical workspace, and the ways in which workspace changes affected employees. Past researchers had not focused heavily on employee preferences for work environments, nor on job level and job family as predictors of these preferences. Therefore, this study took a novel approach by investigating both job level and job family as predictors of employee preferences for the physical workspace, while also exploring the moderating impacts of gender and age. The following sections contain a summary of findings, theoretical and practical implications, strengths, limitations, and recommendations for future research.

\section{Summary of Results}

The first research question asked how job level (manager versus non-manager) related to employee preferences for the three dimensions of the physical work environment. No significant relationship was observed between job level and employee preferences for two dimensions (physical structure and symbolic artifacts). This implies that managers and non-managers did not differ in their desired levels of workspace openness and aesthetic appeal. However, a significant difference was found between managers and non-managers in their preferences for the physical stimuli dimension of the environment, with non-managers more strongly preferring cleaner, quieter workspaces than managers. This finding may have been a result of employees longing for environmental conditions that they did not have: most non-managers in the organization were seated in open and visible (and therefore noisier) spaces with more visual 
distractions. Therefore, it makes sense that a non-manager would express a greater desire for a quieter workspace.

The second research question explored the relationship between job family and employee preferences for the three dimensions of the physical work environment. Employees in engineering, finance, human resources, and marketing/communications did not differ markedly in their preferences for the physical workspace. This lack of significant relationships suggests that employee workspace preferences were similar, despite differences in job duties and responsibilities.

To further understand the findings above, gender was examined as a potential moderator in the relationships between job level/job family and physical environment preferences. Gender did not moderate the relationships between job level and preferences for two dimensions, physical structure and physical stimuli. However, there was a significant interaction between job level and gender for the symbolic artifact dimension (the stylistic appearance of the workspace). Female managers had stronger preferences for symbolic artifacts than female non-managers, though no difference was found between male managers and non-managers. This could be due to the sample surveyedwithin the organization, most managers were not women. Thus, it might be the case that female managers more strongly desire a workspace containing symbols of power and/or authority. In summary, employees were similar in their preferences for the layout and level of distraction within the environment, and only female managers were significantly more opinionated in terms of the symbolic artifacts within their workspaces. 
Next, gender was examined as a moderator between job family and preferences for the physical workspace. Based on the findings, gender was not a moderator between job family and preferences for the symbolic artifact dimension. However, gender moderated the relationship between job family and preferences for two dimensions, physical structure and physical stimuli, and did so in different ways. To be specific, female engineers more strongly preferred a closed, private workspace (physical structure) than female non-engineers, whereas male engineers did not differ from non-engineers. Perhaps female engineers preferred more private workspaces than female non-engineers because their roles required more concentration, and closed office arrangements were conducive to those roles. Furthermore, female engineers more strongly preferred a workspace with few attention-grabbing sights and sounds (physical stimuli), compared to female nonengineers. However, male engineers and non-engineers preferred the opposite. Perhaps this might be because professional women (i.e., female engineers) need less distraction while working compared to male professionals.

In summary, for physical structure, only female engineers preferred a more closed workspace, whereas male engineers did not have a preference. For physical stimuli, both male and female engineers had strong preferences, though in opposite directions: female engineers preferred a less cluttered and noisy environment, but male engineers preferred a more cluttered and noisy environment. Finally, both female and male engineers had similar preferences for symbolic artifacts, or the style of their workspaces.

Age was then examined as a moderator between job level/job family and preferences for each dimension. Based on the results, there was no significant interaction between job 
level and age for any of the three dimensions of the physical workspace. Similarly, there was no significant interaction between job family and age for preferences of any of the three dimensions. This was unexpected, considering past research citing markedly different preferences between employees of varying age groups (Niemczyk \& Ulrich, 2009).

\section{Theoretical Implications}

The results of this study introduced new perspectives surrounding the study of physical work environments. Prior research on the physical work environment has primarily focused on the outcomes of the environment (Brennan et al., 2002; Haynes et al., 2017; Ricciotti et al., 2014). There has, however, been little research involving predictors of preferences for the physical workspace (Luck, 2003). This study built on existing theory by identifying predictors of preferences, along with moderators between those relationships.

Although Luck (2003) was unable to identify significant relationships between particular employee characteristics and preferences for the physical environment in her original study, the current study built on the idea by observing alternative potential predictors. The outcomes of the present study support the idea that strength of employee preferences for the physical environment can be predicted by certain employee characteristics (i.e., job level, job family, and gender). These predictive relationships include the following: non-managers have stronger preferences for physical stimuli, female managers have stronger preferences for symbolic artifacts, female engineers have stronger preferences for physical structure, and female and male engineers have stronger 
(and opposite) preferences for physical stimuli. The latter outcomes support Malone's (1983) finding that job family is related to employee preferences for the physical workspace. Unlike Niemczyk and Ulrich's (2009) study of generation as a predictor of employee preferences for physical environment, in the current study, age did not moderate the relationship between job level/job family and workspace preferences.

The interactions between gender and job level, as well as gender and job family could be explained by the employees' environmental conditions. In this organization, where female leadership was scarce, perhaps female managers had stronger preferences for symbolic artifacts because they sought workspaces that demonstrated power and status. Gender also moderated female engineers' preferences for physical structure, such that female engineers preferred a more closed and private workspace - perhaps professional women (i.e., female engineers) were more negatively impacted by interruptions, so a closed workspace would prevent interruptions and enable the concentration required for work. Finally, gender moderated female and male engineers' preferences for physical stimuli in opposite directions: female engineers preferred a more orderly, quite space, whereas male engineers preferred a more cluttered, noisy space. Perhaps female engineers viewed visual and auditory stimuli as inhibitors of productivity, whereas male engineers viewed visual and auditory stimuli as promoters of productivity. This contradicts Haynes et al. (2017) who suggest that women view interruptions as positive or productive occurrences, although this may be due to job level, which the authors did not investigate. The findings above add to the literature presented throughout the current study, as previous researchers have not yet addressed these moderating effects. 


\section{Practical Implications}

At most organizations, it is not possible to suit all employees' preferences in a single work environment, and it is not practical to create specially-designed spaces per each individual employee. Fortunately, the results of the present study serve as early steps in the pursuit of the best possible workspace. The descriptive statistics support that employees in the sample had the strongest preferences for the physical stimuli dimension, meaning that overall, employees most preferred a physical environment that was quiet and clutter-free. Organization leaders should take this into account when prioritizing which dimensions of a physical environment will be redesigned.

In terms of job level, the results of this study demonstrated that female managers had the strongest preferences for symbolic artifacts in a workspace (compared to female nonmanagers). This means the visual, stylistic appeal of a physical environment is important to female managers. If employers aim to please female managers, they should carefully design symbolic artifacts within the workspace. For example, this could entail careful selection of colors of walls, types of flooring, or symbolism of objects within the workspace. Because female managers did not have strong preferences for physical structure nor physical stimuli, employers who want to satisfy this demographic should not prioritize altering the layout nor level of distraction within the environment.

In terms of job family, this study had more complex findings as function of the gender of employees. First, female engineers' preferences for the physical environment were stronger than female non-engineers' preferences in terms of physical structure. In other words, female engineers more strongly preferred a closed, private workspace than 
female non-engineers. Thus, employers who seek to satisfy female engineers' preferences should attempt to provide a closed and private physical environment. Female nonengineers and males from all job families did not have strong preferences for physical structure, and therefore, organizations do not need to accommodate their preferences on this dimension.

Job family was also an important predictor of preferences for physical stimuli. More specifically, female engineers had stronger preferences than female non-engineers in terms of the noise and clutter levels in the physical environment. Interestingly, male employees differed in the opposite direction: male engineers more strongly preferred a workspace with higher noise levels and more clutter (compared to male non-engineers). For these reasons, organizations interested in pleasing female engineers should consider offering a clean, quiet physical environment. Alternatively, organization leaders interested in pleasing male engineers should provide a workspace with ambient noise and less neatness. In conclusion, the results of this study provide guidance for practitioners who are interested in adjusting various dimensions of the workspace to better accommodate the preferences of diverse subsets of employees.

\section{Strengths, Limitations, and Future Research}

One strength of the current study is that it observed employee preferences for physical environment, which is a relatively novel construct. Past studies have heavily focused on employee satisfaction with the current physical environment. Furthermore, the current study did not attempt to identify the components of the ideal workspace; rather, the study demonstrated the existence of diverse opinions and perspectives held by 
different types of employees within the same organization (e.g., managers, nonmanagers, engineers, non-engineers). This is important because the universal ideal workspace likely does not exist. Rather, employees' notions of the ideal workspace could vary based on work-related traits of the employee (such as job level and job family), as well as demographic traits (such as gender).

Another strength of this study involves the sample. All participants in the study were employees at the same location of the same company. Therefore, when participants expressed their preferences on the instrument, each had a common workspace to serve as a benchmark point of reference. The sample was also composed of roughly $25 \%$ managers and $75 \%$ non-managers; thus, the job level dispersion was representative of the population within the company.

Perhaps the most noticeable limitation of the current study is the relatively small sample size of 157 employees. In addition, the results of statistical analyses may have been skewed due to a larger proportion of male than female participants (91 men compared to 53 women). Similarly, the job family variable was composed of predominantly engineers $(n=94)$, compared to the numbers of finance, human resources, and marketing/communications employees ( $n=21$ for each). This is because in the months leading up to data collection, the organization announced an initiative to redesign the area of the building in which engineers sat. This circumstance is a limitation because employees in the engineering job family may have been more motivated to provide honest, well-thought out responses compared to employees from other job families, who were not expecting a change of physical environment. 
Future researchers should collect additional demographic data from survey participants, beyond age and gender. This will help reveal additional predictors and/or moderators related to employee preferences. Variables such as tenure, hours worked per week, or ethnicity could produce interesting results to build on the current study, because these employee traits have been used in past studies and are easily measured and understood. Future researchers should re-examine age as a predictor or moderator related to employee preferences for the physical workspace. Because the current study divided age group into three sections, future researchers should opt to examine age as a continuous variable or establish different age groups than those used in the current study. Age should be revisited as a potential moderator because the current study's lack of significant findings contradict the findings of numerous past studies.

Finally, the instrument used in the current study could be improved. When designing future instruments, researchers should reevaluate Davis's (1984) dimensions of the physical environment, along with others (including those proposed by Becker and Steele [1995] and Vilnai-Yavetz et al. [2005]). The current study also utilized a 5-point Likertstyle scale, and as a result, responses hovered near the midpoint. Future researchers should consider using a 7-point scale to disperse responses further from the neutral midpoint, resulting in more diverse responses and, thus, a richer understanding of diverse employee preferences. 


\section{Conclusion}

Results of the current study reveal that employee preferences for the physical environment varied based on job level, job family, and gender. Though some preferences differed significantly between (and within) groups, preferences were fairly neutral overall. Because redesigning a physical work environment requires significant time, effort, and other resources, employers should be aware of employees' preferences prior to undertaking such a project. Employers would be well advised to consider employee characteristics as predictors of preferences throughout the space planning process. In closing, this preliminary investigation of employee preferences for the physical environment will be useful in future theory and practice. 


\section{References}

Armstrong-Stassen, M. (2001). Reactions of older employees to organizational downsizing: The role of gender, job level, and time. The Journals of Gerontology Series B: Psychological Sciences and Social Sciences, 56, 234-243.

Becker, F. D., \& Steele, F. (1995). Workplace by design: Mapping the high-performance workscape. San Francisco, CA: Jossey-Bass.

Berger, W. (1999). Lost in space. Wired Magazine, 7(2).

Brennan, A., Chugh, J. S., \& Kline, T. (2002). Traditional versus open office design: A longitudinal field study. Environment and Behavior, 34, 279-299.

Carlopio, J., \& Gardner, D. (1995). Perceptions of work and workplace: Mediators of the relationship between job level and employee reactions. Journal of Occupational and Organizational Psychology, 68, 321-326.

Compensation - Job Families. (n.d.). MIT Human Resources. Retrieved November 21, 2017, from http://hrweb.mit.edu/compensation/job-evaluations/job-families

Davis, T. R. V. (1984). The Influence of the Physical Environment in Offices. Academy of Management Review, 9, 271-283.

Dizik, A. (2016, October 02). Open offices are losing some of their openness. The Wall Street Journal. Retrieved from https://www.wsj.com/articles/open-offices-arelosing-some-of-their-openness-1475460662

Doorley, S., \& Witthoft, S. (2012). Make space: How to set the stage for creative collaboration. Hoboken, NJ: J. Wiley.

Haynes, B., Suckley, L., \& Nunnington, N. (2017). Workplace productivity and office type: an evaluation of office occupier differences based on age and gender. Journal of Corporate Real Estate, 19, 111-138.

Luck, G. (2003). The relationship of an innovative thinking style, locus of control and perceived control on job satisfaction and workspace preferences among knowledge workers. Dissertation Abstracts International, 65, 2133.

Malone, T. (1983). How Do People Organize Their Desks? Implications for the Design of Office Information Systems. ACM Transactions on Office Information Systems, 1, 99-112. 
Niemczyk, M., \& Ulrich, J. (2009). Workplace preferences of millennials in the aviation industry. International Journal of Applied Aviation Studies, 9, 207-219.

Oldham, G. R., \& Brass, D. J. (1979). Employee Reactions to an Open-Plan Office: A Naturally Occurring Quasi-Experiment. Administrative Science Quarterly, 24, 267-284.

Oseland, N. (2009). The impact of psychological needs on office design. Journal of Corporate Real Estate, 11, 244-254.

Paliadelis, P. (2013). Nurse managers don't get the corner office. Journal of Nursing Management, 21, 377-386.

Reh, J. (2017, November 26). The role and responsibilities of a manager. Retrieved from https://www.thebalance.com/what-is-a-manager-2276096

Ricciotti, H. A., Armstrong, W., Yaari, G., Campion, S., Pollard, M., \& Golen, T. H. (2014). Lessons from Google and Apple: Creating an open workplace in an academic medical department to foster innovation and collaboration. Academic Medicine, 89, 1235-1238.

Stellman, J. M., Klitzman, S., Gordon, G. C., \& Snow, B. R. (1987). Work environment and the well-being of clerical and VDT workers. Journal of Occupational Behavior, 8, 95-114.

Stier, H., \& Lewin-Epstein, N. (2003). Time to work: A comparative analysis of preferences for working hours. Work and Occupations, 30, 302-326.

Vecchio, R. P., \& Boatwright, K. J. (2002). Preferences for idealized styles of supervision. The Leadership Quarterly, 13, 327-342.

Vilnai-Yavetz, I., Rafaeli, A., \& Schneider Yaacov, C. (2005). Instrumentality, aesthetics, and symbolism of office design. Environment and Behavior, 37, 533-551. 


\section{Appendix}

Survey Items

\section{Preferences for the Physical Environment Items}

Physical Structure

1. My preference is to work in a private office rather than a shared workspace.

2. I like to work in an open office (shared space).

3. It is important for my building to provide casual meeting spaces.

4. I prefer to work from home.

5. I like others to be able to see me while I work.

6. It is important to be able to speak with someone without first having to knock on a closed office door.

\section{Physical Stimuli}

7. I like when there is some background noise in my work environment.

8. I do my best work in a quiet work environment.

9. Clutter in my workspace is distracting to me.

10. I like to have my workspace well organized.

11. I need control of the sights and sounds around me while I am working.

12. At work, I enjoy hearing others interact with each other.

Symbolic Artifacts

13. It is important for the walls around me at work to be painted a nice-looking color.

14. I like to personalize my work environment with pictures or artwork.

15. I prefer to have a pretty view while I am working.

16. My workspace is symbolic of my status as an employee.

17. It is important to have my company display artwork in the work environment.

18. If I could change the color scheme of my current workspace, I would. 